\title{
Respon kapasitas daya tahan dan aldosterone: Efek minuman isotonik
}

\author{
Nur Azis Rohmansyah ${ }^{1}$ *, Wulan Rahmadhani ${ }^{2}$, Setiyawan Setiyawan ${ }^{1}$, Ashira Hiruntrakul ${ }^{3}$ \\ ${ }^{1}$ Universitas PGRI Semarang. J1. Sidodadi Timur Nomor 24 - Dr. Cipto Semarang, 50232, Indonesia \\ ${ }^{2}$ Sekolah Tinggi Ilmu Kesehatan Muhammadiyah Gombong. Jl. Yos Sudarso No. 461 Gombong, jawa \\ Tengah, 54411, Indonesia \\ ${ }^{3}$ Khon Kaen University. 123 Moo 16 Mittraphap Rd., Muang District, Khon Kaen 40002, Thailand \\ * Corresponding Author. Email: nurazisrohmansyah@kkumail.com
}

Received: 18 June 2020; Revised: 29 July 2020; Accepted: 3 September 2020

\begin{abstract}
Abstrak: Ada kepercayaan umum bahwa minuman istonik berpotensi meningkatkan daya tahan dan aldosterone pada saat latihan dan pemulihan. Namun kepercayaan itu perlu dikaji ulang karena masih bisa untuk diperdebatkan dan lebih banyak lagi bukti empiris. Penelitian ini bertujuan untuk menguji minuma isotonik, air dan kontrol pada respon fisiologis, termasuk kapasitas daya tahan dan aldosterone pada saat latihan dan pemulihan pada saat cuaca panas. Dua belas atlet sepakbola prosseional dari Khon Kaen FC, Thailand yang terlibat dalam penelitian ini. Lari $3000 \mathrm{~m}$, pemulihan $1 \mathrm{jam}$, dan waktu untuk uji kelelahan dilakukan dalam penelitian ini. Hasil penelitian menunjukkan tidak adanya respon fisiologis selama lari 3000 $\mathrm{m}$ dan pada saat pemulihan, denyut jantung lebih rendah dalam uji coba minuman isotonik dibandingkan dengan air dan control. Adanya perbedaan suhu oral, detak jantung, aldosteron, glukosa darah, dan natrium pada saat tes kapasitas daya tahan. Dapat dikatakan bahwa konsumsi minuman isotonik dapat meningkatkan kapasitas daya tahan dan mempertahankan aldosteron lebih efektif daripada dengan atau tanpa air yang mungkin disebabkan oleh peningkatan retensi cairan.
\end{abstract}

Kata Kunci: isotonik; air; daya tahan; aldosterone

\section{The response of endurance capacity and aldosterone: Effects of isotonic drinks}

\begin{abstract}
There is a general belief that isotonic drink has the potentials to improve the endurance and the aldosterone during the exercise and the recovery. Such belief should be revisited again since it is arguable and it needs more empirical evidence. With regards to the statement, the current study aims at testing the isotonic drink, the water, and the control on the physiological response, including the endurance capacity and the aldosterone during the exercise and the recovery under the hot weather. During the study, 12 football players from Khon Kaen FC, Thailand, were selected as the participants. Then, the participants underwent 3000-m run and 1-hour recovery; in this occasion, the researchers recorded the time for the exhaustion test. The results of the study show that there is not any physiological response during the 3000-m run and during the recovery period the heartbeat is slower within the isotonic drink experiment in comparison to the water experiment and the control experiment. At the same time, the results of the study also show that there are differences on the oral temperature, the heartbeat, the aldosterone, blood glucose, and the natrium during the endurance capacity test. Therefore, it can be concluded that isotonic drink is able to improve the endurance capacity and retain the aldosterone more effectively in comparison to water or to the absence of water, which can possibly be caused by the increase on the liquid retention.
\end{abstract}

Keywords: isotonic; water; endurance; aldosterone

How to Cite: Rohmansyah, N., Rahmadhani, W., Setiyawan, S., \& Hiruntrakul, A. (2020). Respon kapasitas daya tahan dan aldosterone: Efek minuman isotonik. Jurnal Keolahragaan, 8(2), 174-182. doi:https://doi.org/10.21831/jk.v8i2.32542

\section{PENDAHULUAN}

Latihan olahraga dengan intensitas sedang sampai dengan tinggi dapat menyebabkan adanya penipisan pada simpanan glikogen otot (Thomas et al., 2009) yang dapat merusak tersediaan kontraksieksitasi (Urdampilleta et al., 2015) dan selanjutnya akan berdampak pada penurunan kinerja. Selain itu, 
defisit cairan selama latihan selama durasi panjang juga dapat terjadi (Pruna et al., 2016), khususnya saat latihan dilakukan dalam kondisi cuaca panas $\left(>30^{\circ} \mathrm{C}\right)$ (Coso et al., 2008) dan lingkungan lembab > 60\% (berdasar pada 30-60\% kelembapan normal) (Lee et al., 2011).

Berolahraga dalam jangka waktu yang lama dan dalam cuaca panas tanpa asupan cairan yang memadai dapat menyebabkan dehidrasi dan hipertermia (Paik et al., 2009), yang keduanya diyakini memiliki efek negatif karena perkembangan stress oksidatif (Hillman et al., 2011) dan kardiovaskular (Cheuvront et al., 2010). Selanjutnya, hiperosmolalitas dan penyusutan sel serta apoptosis, juga dapat terjadi tanpa adanya penggantian cairan (Hillman et al., 2011). Defisit cairan lebih dari 3\% dari massa tubuh selama latihan dapat menyebabkan penurunan yang signifikan dalam kontrol motorik, waktu reaksi (Hoffman et al., 2012), kekuatan aerobik (Casa et al., 2010), dan kapasitas daya tahan (Rollo \& Williams, 2010). Lebih lanjut bahwa asupan air saja sebagai strategi rehidrasi dapat menyebabkan hiponatremia dan bahan-bahan dalam air minum tidak mencukupi untuk pasokan energi (Urdampilleta et al., 2015). Akibatnya, asupan elektrolit dan karbohidrat selama latihan yang berkepanjangan (Čugura et al., 2014) dalam cuaca panas dapat mewakili strategi nutrisi untuk mengurangi potensi penghentian kinerja.

Minuman yang dibuat khusus untuk berolahraga digunakan oleh para atlet sebelum, selama, dan setelah berolahraga (Čugura et al., 2014) untuk mengatasi kelelahan (Logan-Sprenger et al., 2011). Karakteristik minuman isotonik harus berbeda dalam hal kandungan yang digunakan untuk latihan olahraga (Urdampilleta et al., 2015). Misalnya, minuman hipotonik (4-6\% karbohidrat, 0,5-0,7 g/L dari soda) sebelum berolahraga, isotonik (6-9\% karbohidrat, 0,5-0,7 g/L natrium) selama berolahraga, dan hipertonik (9-10\% karbohidrat, 1-1,5 g/L natrium) setelah berjalan lama (Maughan \& Shirreffs, 2004). Namun, dalam cuaca panas, konsentrasi natrium harus ditingkatkan menjadi 0,7-1,2 g/L ketika olahraga lebih lama dari 1 jam (Urdampilleta et al., 2015). Minuman isotonik yang komersial sekarang ini mengandung air untuk melawan dehidrasi (Čugura et al., 2014), elektrolit, yaitu natrium, untuk menghindari hiponatremia dan hipertermia (Urdampilleta et al., 2015), dan karbohidrat untuk meningkatkan kandungan glikogen otot (Lee et al., 2011).

Aldosteron, hormon steroid yang dikeluarkan oleh korteks adrenal, adalah mineralokortikoid yang paling kuat (Vaidya et al., 2015). Aldosteron bertanggung jawab untuk homeostasis cairan dan volume darah melalui reabsorpsi natrium dan klorida melalui tubulus ginjal dan mengekskresikan kalium dan ion hidrogen melalui urin (Catena et al., 2017), oleh karena itu, aldosteron memainkan fungsi penting dalam tubuh manusia selama latihan dalam cuaca panas yang berkepanjangan. Sebagian besar penelitian yang telah meneliti efek minuman isotonik yang komersial dimana telah difokuskan pada kapasitas daya tahan bersepeda (Čugura et al., 2014; Lee et al., 2011; Rollo \& Williams, 2010), dan elektrolit natrium dan kalium (Palmer \& Spriet, 2008). Namun, belum ada penelitian yang menyelidiki respon aldosteron terhadap konsumsi minuman isotonik.

Oleh karena itu, penelitian ini bertujuan untuk menyelidiki pengaruh konsumsi minuman isotonik selama latihan dan pemulihan pada kapasitas daya tahan, aldosteron dan respon fisiologis lainnya (detak jantung, glukosa darah, suhu oral, dan natrium) dalam cuaca panas dibandingkan dengan konsumsi air. Hipotesisnya adalah bahwa konsumsi minuman olahraga isotonik yang komersial akan lebih efektif dalam meningkatkan kapasitas daya tahan, dimungkinkan karena kandungan isinya yang dapat mempertahankan volume plasma.

\section{METODE}

\section{Peserta}

Dua belas atlet sepakbola professional yang terlatih dari Khon Kaen FC, Thailand direkrut dalam penelitian ini. Karakteristik deskriptif peserta disajikan dalam Tabel 1.

Semua atlet terbiasa berlatih lima kali seminggu. Sebelum penelitian ini dilaksanakan, formulir informed consent disediakan untuk semua peserta. Penelitian ini dilakukan sesuai dengan standar etika komite penelitian nasional dan dengan Deklarasi Helsinki 1964.

\section{Desain eksperimental}

Peserta melakukan tiga percobaan eksperimental dimana mereka meminum minuman isotonik komersial, air, atau placebo (kontrol). Penelitian ini dimulai pada waktu yang sama yaitu pukul 07.15 pagi untuk mempertahankan ritme latihan mereka dan diuji coba secara acak serta diberi jeda tujuh hari untuk menyelesaikan pemulihan (Lee et al., 2011). Minuman diberikan dalam desain cross-over, dengan 
menyediakan dua kali lipat minuman isotonik dan air. Setiap percobaan terdiri dari tiga fase: (1) lari $3000 \mathrm{~m}$; (2) 1 jam pemulihan di laboratorium; dan (3) uji kapasitas daya tahan.

Tabel 1. Karaktersitik subjek

\begin{tabular}{ll}
\hline Variabel & Mean \pm SD \\
Umur (tahun) & $24,33 \pm 2,76$ \\
Tinggi Badan $(\mathrm{cm})$ & $170,12 \pm 3,57$ \\
Berat Badan $(\mathrm{kg})$ & $60,22 \pm 2,72$ \\
$\mathrm{IMT}\left(\mathrm{kg} / \mathrm{m}^{2}\right)$ & $20,12 \pm 0,56$ \\
Denyut jantung istirahat (bpm) & $50,45 \pm 2,65$ \\
VO $_{2 \max }$ & $61,13 \pm 3,87$ \\
Volume latihan (menit/minggu) & $615,49 \pm 60,76$ \\
Pengalaman latihan (tahun) & $9,87 \pm 2,35$ \\
\hline
\end{tabular}

\section{Prosedur Penelitian}

Sebelum dimulainya uji coba, para peserta mengunjungi laboratorium tiga kali. Pada kunjungan pertama, karakteristik peserta diukur. Setelah pada kunjungan kedua dan ketiga (dua hari), setiap atlet dibiasakan dengan treadmill (Chicago X2) pada kecepatan yang berbeda selama setidaknya 15 menit, yang dilakukan untuk membiasakan irama. Semua atlet diperintahkan untuk mengontrol konsumsi makanan mereka 24 jam sebelum dimulainya setiap percobaan eksperimental untuk tidak mempengaruhi kinerja mereka. Para atlet diminta untuk menghindari pelatihan intensif, aktivitas fisik dan menahan diri dari sarapan, kopi, dan alat bantu ergonomi selama 24 jam sebelum setiap percobaan. Mereka diminta puasa di malam hari dan untuk tiba di lokasi pada jam 7:00 pagi. Atlet mengenakan pakaian dan sepatu yang sama untuk setiap percobaan.

\section{Protokol hidrasi}

Semua atlet diinstruksikan untuk minum $500 \mathrm{ml}$ air 2 jam sebelum dimulainya uji coba dan tidak perbolehkan untuk makan dan minum setelahnya (Lee et al., 2011). Bahan minuman isotonik dan air dijelaskan pada Tabel 2.

Tabel 2. Komposisi minuman

\begin{tabular}{lll}
\hline Konten & Minuman Isotonik & Air \\
\hline Energi $(\mathrm{kcal} / \mathrm{L})$ & 24 & 0 \\
Protein $(\mathrm{g} / \mathrm{L})$ & 0 & 0 \\
Lemak $(\mathrm{g} / \mathrm{L})$ & 0 & 0 \\
Total gula $(\mathrm{g} / \mathrm{L})$ & 5.9 & 0 \\
Karbohidrat $(\mathrm{g} / \mathrm{L})$ & 5.9 & 0 \\
$\mathrm{Na}+(\mathrm{mmol} / \mathrm{L})$ & 21 & 2 \\
$\mathrm{~K}+(\mathrm{mmol} / \mathrm{L})$ & 5 & 0.7 \\
$\mathrm{pH}$ & 7.1 & 7.0 \\
\hline
\end{tabular}

Catatan: Konten energi, elektrolit dan makroutrien diperoleh dari label produsen minuman

Minuman ini disajikan pada suhu $18{ }^{\circ} \mathrm{C}$. Para atlet diberikan asupan $150 \mathrm{ml}$ minuman isotonik atau air setelah 5 menit awal lari $3000 \mathrm{~m}$. Selama masa pemulihan, atlet diminta untuk minum $150 \mathrm{ml}$ minuman isotonik atau air setiap 15 menit. Total volume setiap minuman adalah $750 \mathrm{ml}$. Minuman disajikan dalam botol yang tidak bisa dibedakan, sehingga para peserta tidak tahu minuman apa yang mereka minum.

\section{Lari $3000 \mathrm{~m}$}

Peserta memasuki lintasan stadion dan menyelesaikan pemanasan 10 menit termasuk 4 menit peregangan. Kemudian, mereka berlari $3000 \mathrm{~m}$ di lintasan dimana suhu lingkungan hangat di ketiga uji coba $\left(25-28^{\circ} \mathrm{C}\right)$ dengan kelembaban relatif normal $49-52 \%$. Atlet diperintahkan untuk berlari setiap putaran di trek dalam 1,5 menit untuk menghindari mencapai denyut jantung pada $160 \mathrm{bpm}$ untuk mencegah ketegangan miokard (Tortora \& Derrickson, 2010), kemungkinan kelelahan, dan kehilangan cairan yang tinggi melalui keringat. Denyut jantung dipantau menggunakan monitor detak jantung (Galaxy Watch Active 2, Korea Selatan). Suhu lingkungan dan kelembaban relatif diamati menggunakan termohygrometer (HTC-1, Cina). Seluruh lari 3000 m membutuhkan waktu 11,45-12,00 menit. 


\section{Periode Pemulihan}

Setelah menyelesaikan lari $3000 \mathrm{~m}$, atlet keluar dari lintasan dan memasuki ruangan di laboratorium dimana suhu sekitar diatur pada $22^{\circ} \mathrm{C}$. Para atlet duduk beristirahat di ruang tengah selama satu jam, di saat bersamaan mereka meminum minuman mereka. Pemulihan memastikan kembalinya otot ke kondisi sebelum latihan setelah uji coba. Disarankan bahwa periode pemulihan memastikan kinerja dalam kapasitas daya tahan tes berikutnya.

\section{Tes Kapasitas Daya Tahan}

Setelah periode pemulihan, atlet menyelesaikan tes kapasitas daya tahan dalam semua uji coba pada suhu panas $\left(31-33^{\circ} \mathrm{C}\right)$ dan kelembaban relatif normal (44-47\%). Kapasitas daya tahan (uji waktu hingga kelelahan) dilakukan di treadmill (Lee et al., 2011). Setelah 5 menit pemanasan standar di treadmill, atlet dimulai dengan berlari pada kecepatan $8 \mathrm{~km} / \mathrm{jam}$, kemudian meningkat $1 \mathrm{~km} / \mathrm{jam}$ setiap lima menit sampai batas ambang peserta kehabisan tenaga. Atlet menerima dorongan verbal untuk terus berlari selama mungkin. Toleransi berlari didefinisikan sebagai ketidakmampuan untuk mempertahankan irama langkah teratur di treadmill. Pada saat itu, peneliti menekan tombol berhenti darurat, dan waktu untuk kelelahan dicatat.

\section{Pengumpulan dan Analisis Sampel Darah}

Sampel darah dikumpulkan dari masing-masing atlet dalam tiga percobaan dan ditarik dari median vena lengan kiri atlet. Sampel diambil pada pra-percobaan, segera setelah lari 3000 m, pada akhir periode pemulihan, dan segera setelah uji kapasitas daya tahan. Sebanyak $3 \mathrm{ml}$ darah ditransfer ke dalam tabung polos yang berisi aktivator gumpalan darah untuk mengukur glukosa darah menggunakan Integral 400 (Swiss), dan $3 \mathrm{ml}$ ditransfer ke dalam tabung EDTA. Suhu oral diukur dengan Digital thermometer-SDT-10A (Samsung, Korea). Tabung darah polos disentrifugasi pada $3{ }^{\circ} \mathrm{C}$ dan 3500 putaran $/$ menit selama 10 menit untuk memungkinkan ekstraksi serum. Serum digunakan untuk mengukur konsentrasi natrium menggunakan ALI 480 Beckman electrolyte analyzer (CO, Jepang) dan hormon aldostone menggunakan immunoassay chemiluminescent (Elecsys Roche $\mathrm{GmbH}$, Jerman). Rentang referensi variabel adalah sebagai berikut: 3,9-6,1 $\mathrm{mmol} / \mathrm{L}$ untuk glukosa darah, $111-860 \mathrm{pmol} / \mathrm{L}$ untuk serum aldosteron, $135-152 \mathrm{mmol} / \mathrm{L}$ untuk serum. Kisaran suhu normal tubuh adalah $36,6-37,4^{\circ} \mathrm{C}$.

\section{Analisis statistik}

Statistik deskriptif dilaporkan sebagai mean \pm standar deviasi (SD). Signifikansi pada $p<0,05$ untuk semua analisis. Tes Shapiro-Wilk untuk memeriksa distribusi normal. Semua variabel (aldosteron, suhu oral, glukosa darah, denyut jantung, dan natrium) pada semua titik waktu protokol terdistribusi secara normal $(p>0,05)$. Analisis varians pengukuran berulang (ANOVA) dengan koreksi GreenhouseGeisser digunakan untuk menentukan kemungkinan perbedaan antara uji coba dalam respons fisiologis dan kapasitas daya tahan. Ketika tingkat $\mathrm{F}$ signifikan dicapai, tes post-hoc menggunakan koreksi Bonferroni digunakan untuk perbandingan berpasangan menggunakan cara yang disesuaikan. Analisis statistik dilakukan dengan menggunakan SPSS versi 20.0.

\section{HASIL DAN PEMBAHASAN}

Tidak ada perbedaan signifikan dalam parameter fisiologis (aldosteron, suhu oral, glukosa darah, denyut jantung, dan natrium) yang diukur sebelum dimulainya semua percobaan eksperimental (Tabel $3)$.

Tabel 3. Pre-uji coba parameter fisiologi

\begin{tabular}{lllll}
\hline Parameter & Isotonik & Air & Kontrol & $\mathrm{p}$ \\
\hline Aldosterone (pmol/l) & $417,14 \pm 5,43$ & $429,14 \pm 6,11$ & $420,97 \pm 5,70$ & 0,477 \\
Total Suhu Oral (C) & $36,90 \pm 0,08$ & $36,84 \pm 0,05$ & $36,88 \pm 0,06$ & 0,210 \\
Glukosa Darah (mmol/l) & $5,39 \pm 0,17$ & $5,40 \pm 0,35$ & $5,41 \pm 0,33$ & 0,847 \\
Denyut Jantung (bpm) & $51,14 \pm 1,65$ & $51,10 \pm 1,43$ & $51,15 \pm 1,70$ & 0,925 \\
Na+ (Sodium) (mmol/l) & $137,22 \pm 0,78$ & $137,47 \pm 0,56$ & $137,31 \pm 0,56$ & 0,609 \\
\hline
\end{tabular}

Mean \pm SD 
Tidak ada perbedaan antara uji coba untuk parameter fisiologis, memastikan bahwa semua parameter terdistribusi normal ( $\mathrm{p}>0,05)$. Tabel 4 mengilustrasikan hasil respon dari parameter fisiologis ini untuk minuman olahraga isotonik, air, atau kontrol pada tiga titik waktu: (1) setelah lari $3000 \mathrm{~m}$; (2) setelah pemulihan; dan (3) pada kelelahan. Tidak ada perbedaan dalam semua parameter fisiologis setelah lari $3000 \mathrm{~m}$ antara uji coba $(\mathrm{p}>0,05)$. Setelah pemulihan, tidak ada perbedaan yang dicatat dalam parameter fisiologis $(\mathrm{p}>0,05)$ kecuali untuk denyut jantung yang secara signifikan lebih rendah dalam uji coba minuman isotonik $(\mathrm{p}=0,050)$ dibandingkan dengan air dan kontrol.

Saat kelelahan, data menunjukkan tidak ada perbedaan dalam suhu oral dan denyut jantung, tetapi perbedaan terdapat pada aldosteron, glukosa darah, dan natrium (Tabel 4). Post-hoc menggunakan Bonferroni dengan cara yang disesuaikan mengungkapkan bahwa konsentrasi aldostone lebih rendah dengan minuman isotonik dari pada dengan air dan kontrol, kadar glukosa darah meningkat dengan minuman isotonik dari pada dengan air dan kontrol, hal ini mengungkapkan lebih banyak natrium serum dengan minuman isotonik dari pada dengan air dan kontrol. Namun, data melaporkan tidak ada perbedaan aldosteron, glukosa darah, dan natrium antara uji coba air dan kontrol.

Ada perbedaan yang signifikan antara percobaan dalam kapasitas daya tahan (waktu treadmill yang berbeda kecepatan). Kapasitas daya tahan lebih besar dengan minuman isotonic dibandingkan dengan air dan kontrol, tetapi tidak ada perbedaan yang diamati antara air dan kontrol.

Post-hoc dengan alat yang disesuaikan Bonferroni digunakan untuk menentukan perbedaan dalam kapasitas daya tahan antara tiga percobaan. Minuman isotonik berbeda secara signifikan dari percobaan kontrol. Minuman isotonik berbeda secara signifikan dari air. Tidak ada perbedaan antara uji coba air dan kontrol. Tingkat signifikansi ditetapkan pada $\mathrm{p}<0,05$.

Ada perbedaan yang signifikan antara percobaan dalam kapasitas daya tahan (waktu treadmill yang berbeda kecepatan). Kapasitas daya tahan lebih besar dengan minuman isotonic dibandingkan dengan air dan kontrol, tetapi tidak ada perbedaan yang diamati antara air dan kontrol.

Post-hoc dengan alat yang disesuaikan Bonferroni digunakan untuk menentukan perbedaan dalam kapasitas daya tahan antara tiga percobaan. Minuman isotonik berbeda secara signifikan dari percobaan kontrol. Minuman isotonik berbeda secara signifikan dari air. Tidak ada perbedaan antara uji coba air dan kontrol. Tingkat signifikansi ditetapkan pada $\mathrm{p}<0,05$.

Tabel 4. Hasil respon fisiologi pada isotonic, air dan control setelah lari $3000 \mathrm{~m}$, diikuti pemulihan dan kelelahan pada 12 atlet sepakbola professional Khon Kaen FC, Thailand

\begin{tabular}{lllll}
\hline & \multicolumn{5}{c}{ Setelah lari $3000 \mathrm{~m}$} \\
\hline Parameter & Isotonik & Air & Kontrol & $\mathrm{p}$ \\
Aldosterone (pmol/l) & $513,4 \pm 12,83$ & $518,4 \pm 16,81$ & $520,4 \pm 18,88$ & 0,070 \\
Total Suhu Oral (C) & $37,13 \pm 0.07$ & $37,55 \pm 0,12$ & $37,57 \pm 0,13$ & 0,63 \\
Glukosa Darah (mmol/l) & $5,75 \pm 0,12$ & $5,67 \pm 0,16$ & $5,63 \pm 0,15$ & 0,159 \\
Denyut Jantung (bpm) & $126,72 \pm 3.12$ & $127,40 \pm 1.63$ & $129.15 \pm 1.47$ & 0,268 \\
Na+ (Sodium) (mmol/l) & $141,55 \pm 1.14$ & $142,60 \pm 1.69$ & $142,57 \pm 1.53$ & 0,953 \\
\hline \multicolumn{5}{c}{ Pemulihan } \\
\hline Aldosterone (pmol/l) & $493,39 \pm 7.78$ & $498,74 \pm 8.73$ & $501,07 \pm 8,10$ & 0,258 \\
Total Suhu Oral (C) & $37,28 \pm 0.88$ & $37,41 \pm 0,15$ & $37,45 \pm 0,11$ & 0,412 \\
Glukosa Darah (mmol/l) & $5,41 \pm 0.12$ & $5,34 \pm 0,14$ & $5,35 \pm 0.91$ & 0,238 \\
Denyut Jantung (bpm) & $107,00 \pm 4,37$ & $110,73 \pm 3,35$ & $111,82 \pm 5,82$ & 0,051 \\
Na+ (Sodium) (mmol/l) & $137,15 \pm 0,92$ & $137,09 \pm 0,72$ & $137,80 \pm 0,98$ & 0,777 \\
\hline \multicolumn{5}{c}{ Kelelahan } \\
\hline Aldosterone (pmol/l) & $601,22 \pm 17,57$ & $687,07 \pm 28,02$ & $694,24 \pm 48,21$ \\
Total Suhu Oral (C) & $38,27 \pm 0,22$ & $38,38 \pm 0,19$ & $38,37 \pm 0,22$ & 0,001 \\
Glukosa Darah (mmol/l) & $4,97 \pm 0,22$ & $4,49 \pm 0,39$ & $4,50 \pm 0,37$ & 0,071 \\
Denyut Jantung (bpm) & $168,51 \pm 14,26$ & $169,34 \pm 11,54$ & $171,15 \pm 9,82$ & 0,032 \\
Na+ (Sodium) (mmol/l) & $144,74 \pm 1,94$ & $143,15 \pm 1,18$ & $143,01 \pm 1,26$ & 0,015 \\
\hline
\end{tabular}

Mean \pm SD

\section{Pembahasan}

Hasil penelitian ini mengungkapkan bahwa kapasitas daya tahan (waktu ujicoba di treadmill sampai dengan kelelahan) lebih lama dengan minuman isotonik dari pada dengan air dan kontrol. Hasil ini dapat dijelaskan oleh ketersediaan karbohidrat dalam minuman olahraga selama lari $3000 \mathrm{~m}$ dan pemu- 
lihan, berkontribusi terhadap glikolisis yang dipertahankan selama berlari, terutama pada kecepatan tinggi di treadmill. Perlu dicatat bahwa peningkatan kecil karbohidrat meningkatkan pengambilan glukosa dan cairan (Shirreffs, 2009), memastikan pasokan energi berkelanjutan. Hasil ini sesuai dengan penelitian Lee et al. (2011) yang melaporkan bahwa dalam lingkungan yang panas $\left(32^{\circ} \mathrm{C}\right.$ dan $\left.65 \% \mathrm{rh}\right)$, kapasitas daya tahan yang lebih besar dengan minuman isotonik (1,5 L) sekitar 17,7 menit lebih lama daripada dengan air dan sekitar 13,5 menit lebih lama dibandingkan dengan plasebo dalam aktivitas fisik aktif. Namun, periode pemulihan dalam studi itu adalah 5 jam setelah 75 menit berjalan, yang meningkatkan glikogenesis sebelum memulai tes kapasitas daya tahan. Bilzon et al. (2000) menunjukkan 16 menit lebih lama berjalan dengan karbohidrat-elektrolit dibandingkan dengan plasebo pada pria sehat. Mereka menyarankan bahwa minuman yang mengandung protein cenderung menguntungkan kinerja dari pada karbohidrat atau cairan saja. Stevenson et al. (2009) menemukan peningkatan kinerja dan kewaspadaan pada pegolf pria sebagai akibat dari konsumsi minuman isotonik ( $6,4 \mathrm{~g}$ karbohidrat dan $16 \mathrm{mg}$ kafein per $100 \mathrm{ml}$ ) sebelum pertandingan golf dan $1,6 \mathrm{mg} / \mathrm{kg}$ kafein ditambah $0,64 \mathrm{~g} / \mathrm{kg}$ karbohidrat selama pertandingan. Sebaliknya, Rollo dan Williams (2010) menunjukkan bahwa konsumsi minuman karbohidrat-elektrolit (489 ml air yang mengandung 6,4\% karbohidrat) tidak meningkatkan total jarak lari (13,6 menit) dibandingkan dengan plasebo (13,5 menit) pada pria terlatih.

Temuan utama dari penelitian ini adalah bahwa atlet secara signifikan menyelesaikan tes kapasitas daya tahan dengan konsentrasi aldosteron yang lebih rendah dalam minuman isotonik dibandingkan dengan uji coba air dan kontrol. Hasil ini mungkin dikaitkan dengan penggantian natrium dengan mengonsumsi minuman olahraga isotonik yang dapat meningkatkan homeostasis tekanan darah. Aldosteron diambil dari adrenal cortex sebagai hasil dari sistem renin-angiotensin (Vaidya et al., 2015). Ketika aliran darah berkurang, renin disintesis dari prorenin darah dalam sel-sel juxta-glomerular di ginjal, dikonversi menjadi angiotensin I oleh angiotensinogen yang ditemukan di hati (Tortora \& Derrickson, 2014). Angiotensin I kemudian dikonversi menjadi angiotensin II oleh enzim pengonversi angiotensin, yang menstimulasi sekresi aldosteron dari korpus adrenal (Tortora \& Derrickson, 2014). Aldosteron menstimulasi tubulus ginjal untuk meningkatkan reabsorpsi natrium dan air (Catena et al., 2017) untuk meningkatkan volume plasma dan tekanan darah. Dengan demikian, aldosteron lebih tinggi pada uji air dan kontrol untuk mempertahankan volume plasma dan keseimbangan elektrolit. Selain itu, korelasi antara aldosteron dan natrium paralel. Kandungan natrium yang lebih tinggi dalam minuman olahraga dibandingkan dengan air dapat menjelaskan hal ini. Ketinggian ini dapat mempertahankan volume plasma yang lebih tinggi dan cairan ekstraseluler (Below \& Coyle, 1993), mempromosikan keseimbangan osmosis. Sama halnya dengan natrium dapat meningkatkan kinerja melalui peningkatan retensi cairan selama latihan (Lee et al., 2011). Sejalan dengan ini, Below dan Coyle (1993) menunjukkan bahwa konsumsi $550 \mathrm{mg}$ natrium meningkatkan konsentrasinya dalam aliran darah dan meningkatkan pemeliharaan volume plasma selama 50 menit bersepeda. Lee et al. (2011) juga menemukan tingkat natrium yang lebih tinggi pada kelelahan bersepeda dalam percobaan minuman olahraga dibandingkan dengan air atau plasebo.

Temuan penelitian ini menyiratkan bahwa glukosa darah pada kelelahan meningkat secara signifikan setelah konsumsi minuman isotonik dibandingkan dengan air dan uji coba kontrol. Hasil ini mungkin dikaitkan dengan sintesis glikogen yang cukup selama pemulihan, yang lebih penting adalah bahwa kadar glukosa darah dalam tiga percobaan berada dalam kisaran normal, yang mungkin terkait dengan teori yang menyatakan bahwa glukosa darah meningkat atau dipertahankan saat latihan dilakukan dalam panas (Kay \& Marino, 2000). Selanjutnya, peningkatan glukosa darah dalam panas terkait dengan peningkatan kadar katekolamin (Febbraio et al., 1994), yang bertanggung jawab untuk glikogenolisis. Dengan demikian, glukosa darah tidak mungkin menjadi alasan penghentian latihan dalam penelitian ini.

Denyut jantung rata-rata tidak berbeda antara uji coba di semua titik waktu kecuali untuk mengikuti pemulihan, meskipun kapasitas daya tahan secara signifikan lebih lama dengan minuman isotonik dari pada dengan air dan uji kontrol. Hasil ini dapat dijelaskan oleh peran minuman isotonik dalam persiapan kardiovaskular selama pemulihan, memfasilitasi otot jantung untuk bekerja secara efektif selama tes kapasitas daya tahan. Misalnya, detak jantung dalam penelitian ini secara signifikan lebih rendah dalam uji coba minuman olahraga dibandingkan dengan air dan kontrol (Tabel 4). Lee et al. (2011) mengemukakan bahwa minuman isotonik mengurangi ketegangan kardiovaskular dibandingkan dengan air atau plasebo. 
Data melaporkan bahwa suhu oral rata-rata serupa pada uji coba saat kelelahan. Penjelasan tentang hasil ini mungkin dikaitkan dengan waktu yang dicapai lebih besar untuk kelelahan dalam minuman isotonik. Hasil ini setuju dengan penelitian Lee et al. (2011), yang menemukan bahwa suhu inti rata-rata adalah serupa di uji coba pada kelelahan. Namun, kisaran suhu inti dalam semua percobaan dalam penelitian itu adalah $38,0-39,7^{\circ} \mathrm{C}$, menunjukkan bahwa beberapa suhu atlet telah mencapai titik hipertermia $\left(\geq 39^{\circ} \mathrm{C}\right)$. Dalam penelitian ini, kisaran suhu oral adalah $37,8-38,7^{\circ} \mathrm{C}$. Namun demikian, suhu inti lebih tinggi dari suhu oral sekitar $0,5^{\circ} \mathrm{C}$ (Coso et al., 2008), memastikan bahwa suhu oral atlet dalam penelitian ini mencapai titik hipertermia serupa dengan yang ada dalam studi Lee et al. (2011).

Latihan dalam lingkungan panas atau kondisi panas menimbulkan efek yang menantang pada kemampuan seorang atlet untuk mengendalikan lingkungan internal tubuhnya karena tingginya rasio produksi panas metabolik dan perolehan panas dari lingkungan ((Maughan \& Shirreffs, 2004), yang dapat mengakibatkan pada kejadian hipertermia. Lingkungan yang panas dan lembab merusak termoregulasi karena persaingan antara kulit dan otot-otot aktif untuk aliran darah (Butts et al., 2016). Lebih lanjut, peningkatan yang diinduksi oleh latihan dalam ketegangan termal menghasilkan perubahan dalam aktivitas sentral dan fungsi kontraktil otot (Pointon et al., 2012). Selanjutnya, suhu oral dalam penelitian ini mungkin menjadi alasan utama untuk berhenti berolahraga. Keterbatasan penelitian ini adalah bahwa gravitasi spesifik urin (USG), volume urin, dan hormon atrial natriuretic peptide (ANP) tidak diukur, sehingga penelitian lebih lanjut untuk mengukur variabel-variabel tersebut direkomendasikan.

\section{SIMPULAN}

Menurut komposisi minuman isotonik yang tersedia secara komersial yang dikonsumsi dalam penelitian ini, penelitian lebih lanjut harus membuktikan pentingnya pengaruhnya. Tidak ada penelitian yang mengevaluasi respons hormon aldosteron untuk mengonsumsi minuman isotonik komersial. Berdasarkan temuan saat ini, penelitian ini menyimpulkan bahwa konsumsi minuman isotonik meningkatkan ketinggian konsentrasi aldosteron lebih efektif dari pada dengan atau tanpa konsumsi air. Untuk para atlet yang melakukan berbagai latihan ketahanan dalam satu hari, mengonsumsi minuman isotonik selama latihan dan pemulihan dapat meningkatkan kapasitas daya tahan berikutnya.

\section{DAFTAR PUSTAKA}

Below, P. R., \& Coyle, E. F. (1993). 15 fluid and carbohydrate ingestion individually benefit intense exercise lasting one-hour. Medicine \& Science in Sports \& Exercise, 25(Supplement), S3. https://doi.org/10.1249/00005768-199305001-00016

Bilzon, J. L. J., Allsopp, A. J., \& Williams, C. (2000). Short-term recovery from prolonged constant pace running in a warm environment: the effectiveness of a carbohydrate-electrolyte solution. European Journal of Applied Physiology, 82(4), 305-312. https://doi.org/10.1007/s004210000206

Butts, C. L., Luhring, K. E., Smith, C. R., Tucker, M. A., Moyen, N. E., Ganio, M. S., \& McDermott, B. P. (2016). Effects of mild hypohydration on cooling during cold-water immersion following exertional hyperthermia. European Journal of Applied Physiology, 116(4), 687-695. https://doi.org/10.1007/s00421-016-3329-7

Casa, D. J., Stearns, R. L., Lopez, R. M., Ganio, M. S., McDermott, B. P., Walker Yeargin, S., Yamamoto, L. M., Mazerolle, S. M., Roti, M. W., Armstrong, L. E., \& Maresh, C. M. (2010). Influence of hydration on physiological function and performance during trail running in the heat. Journal of Athletic Training, 45(2), 147-156. https://doi.org/10.4085/1062-6050-45.2.147

Catena, C., Colussi, G. L., Brosolo, G., Bertin, N., Novello, M., Palomba, A., \& Sechi, L. A. (2017). Salt, aldosterone, and parathyroid hormone: What is the relevance for organ damage? International Journal of Endocrinology, 2017, 1-8. https://doi.org/10.1155/2017/4397028

Cheuvront, S. N., Kenefick, R. W., Montain, S. J., \& Sawka, M. N. (2010). Mechanisms of aerobic performance impairment with heat stress and dehydration. Journal of Applied Physiology, 109(6), 1989-1995. https://doi.org/10.1152/japplphysiol.00367.2010

Coso, J. Del, Estevez, E., Baquero, R. A., \& Mora-Rodriguez, R. (2008). Anaerobic performance when rehydrating with water or commercially available sports drinks during prolonged exercise in the heat. Applied Physiology, Nutrition, and Metabolism, 33(2), 290-298. 
https://doi.org/10.1139/H07-188

Čugura, T., Pleština, M., Bursać Kovačević, D., Vahčić, N., Dragović-Uzelac, V., \& Levaj, B. (2014). Influence of storage on quality and sensorial properties of sports drink with lemon juice and isomaltulose. Hrvatski Casopis Za Prehrambenu Tehnologiju, Biotehnologiju i Nutricionizam, 9(3-4). https://hrcak.srce.hr/136296

Febbraio, M. A., Snow, R. J., Hargreaves, M., Stathis, C. G., Martin, I. K., \& Carey, M. F. (1994). Muscle metabolism during exercise and heat stress in trained men: effect of acclimation. Journal of Applied Physiology, 76(2), 589-597. https://doi.org/10.1152/jappl.1994.76.2.589

Hillman, A. R., Vince, R. V., Taylor, L., McNaughton, L., Mitchell, N., \& Siegler, J. (2011). Exerciseinduced dehydration with and without environmental heat stress results in increased oxidative stress. Applied Physiology, Nutrition, and Metabolism, 36(5), 698-706. https://doi.org/10.1139/h11-080

Hoffman, J. R., Williams, D. R., Emerson, N. S., Hoffman, M. W., Wells, A. J., McVeigh, D. M., McCormack, W. P., Mangine, G. T., Gonzalez, A. M., \& Fragala, M. S. (2012). L-alanyl-Lglutamine ingestion maintains performance during a competitive basketball game. Journal of the International Society of Sports Nutrition, 9(1), 4. https://doi.org/10.1186/1550-2783-9-4

Kay, D., \& Marino, F. E. (2000). Fluid ingestion and exercise hyperthermia: Implications for performance, thermoregulation, metabolism and the development of fatigue. Journal of Sports Sciences, 18(2), 71-82. https://doi.org/10.1080/026404100365135

Lee, J. K. W., Nio, A. Q. X., Ang, W. H., Law, L. Y. L., \& Lim, C. L. (2011). Effects of ingesting a sports drink during exercise and recovery on subsequent endurance capacity. European Journal of Sport Science, 11(2), 77-86. https://doi.org/10.1080/17461391.2010.487115

Logan-Sprenger, H. M., Palmer, M. S., \& Spriet, L. L. (2011). Estimated fluid and sodium balance and drink preferences in elite male junior players during an ice hockey game. Applied Physiology, Nutrition, and Metabolism, 36(1), 145-152. https://doi.org/10.1139/H10-098

Maughan, R., \& Shirreffs, S. (2004). Exercise in the heat: challenges and opportunities. Journal of Sports Sciences, 22(10), 917-927. https://doi.org/10.1080/02640410400005909

Paik, I.-Y., Jeong, M.-H., Jin, H.-E., Kim, Y.-I., Suh, A.-R., Cho, S.-Y., Roh, H.-T., Jin, C.-H., \& Suh, S.-H. (2009). Fluid replacement following dehydration reduces oxidative stress during recovery. Biochemical and Biophysical Research Communications, 383(1), 103-107. https://doi.org/10.1016/j.bbrc.2009.03.135

Palmer, M. S., \& Spriet, L. L. (2008). Sweat rate, salt loss, and fluid intake during an intense on-ice practice in elite Canadian male junior hockey players. Applied Physiology, Nutrition, and Metabolism, 33(2), 263-271. https://doi.org/10.1139/H08-011

Pointon, M., Duffield, R., Cannon, J., \& Marino, F. E. (2012). Cold water immersion recovery following intermittent-sprint exercise in the heat. European Journal of Applied Physiology, 112(7), 2483-2494. https://doi.org/10.1007/s00421-011-2218-3

Pruna, G. J., Hoffman, J. R., McCormack, W. P., Jajtner, A. R., Townsend, J. R., Bohner, J. D., La Monica, M. B., Wells, A. J., Stout, J. R., Fragala, M. S., \& Fukuda, D. H. (2016). Effect of acute L-Alanyl-L-Glutamine and electrolyte ingestion on cognitive function and reaction time following endurance exercise. European Journal of Sport Science, 16(1), 72-79. https://doi.org/10.1080/17461391.2014.969325

Rollo, I., \& Williams, C. (2010). Influence of ingesting a carbohydrate-electrolyte solution before and during a 1-hour run in fed endurance-trained runners. Journal of Sports Sciences, 28(6), 593 601. https://doi.org/10.1080/02640410903582784

Shirreffs, S. M. (2009). Hydration in sport and exercise: water, sports drinks and other drinks. Nutrition Bulletin, 34(4), 374-379. https://doi.org/10.1111/j.1467-3010.2009.01790.x

Stevenson, E. J., Hayes, P. R., \& Allison, S. J. (2009). The effect of a carbohydrate-caffeine sports drink on simulated golf performance. Applied Physiology, Nutrition, and Metabolism, 34(4), 681-688. https://doi.org/10.1139/H09-057

Thomas, K., Morris, P., \& Stevenson, E. (2009). Improved endurance capacity following chocolate 


\section{Jurnal Keolahragaan 8 (2), 2020 - 182}

Nur Azis Rohmansyah, Wulan Rahmadhani, Setiyawan Setiyawan, Ashira Hiruntrakul

milk consumption compared with 2 commercially available sport drinks. Applied Physiology, Nutrition, and Metabolism, 34(1), 78-82. https://doi.org/10.1139/H08-137

Tortora, G. J., \& Derrickson, B. (2014). Principles of anatomy \& physiology. John Wiley \& Sons.

Urdampilleta, A., Gómez-Zorita, S., Soriano, J. M., Martínez-Sanz, J. M., Medina, S., \& Gil-

Izquierdo, A. (2015). Hydration and chemical ingredients in sport drinks: Food safety in the European context. Nutricion Hospitalaria, 31(5), 1889-1899.

https://doi.org/10.3305/nh.2015.31.5.7867

Vaidya, A., Brown, J. M., \& Williams, J. S. (2015). The renin-angiotensin-aldosterone system and calcium-regulatory hormones. Journal of Human Hypertension, 29(9), 515-521.

https://doi.org/10.1038/jhh.2014.125 